\title{
Results of surgical treatment of primary lung cancer with synchronous brain metastases
}

\author{
Mariusz Jan Bella ${ }^{1,2}$, Janusz Kowalewski ${ }^{1,2}$, Maciej Dancewicz ${ }^{2}$, Przemysław Bławat ${ }^{2}$, \\ Tomasz Jarosław Szczęsny², Aleksandra Chrząstek ${ }^{1,2}$, Paweł Wnuk ${ }^{1,2}$ \\ ${ }^{1}$ Department of Thoracic Surgery and Tumours, Faculty of Medicine, Nicolaus Copernicus University \\ in Torun, Poland \\ ${ }^{2}$ Department of Thoracic Surgery and Tumours, Oncology Centre, Bydgoszcz, Poland
}

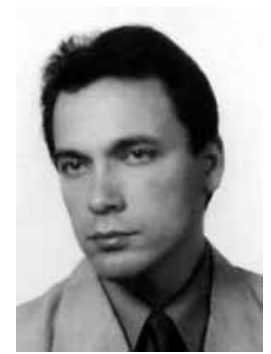

Kardiochirurgia i Torakochirurgia Polska 2015; 12 (1): 14-17

\begin{abstract}
Introduction: The surgical treatment of non-small cell lung cancer (NSCLC) with synchronous brain matastases is more effective than other therapeutic options, but this management is still controversial.

The aim of the study was to evaluate the survival of patients after pulmonary resection NSCLC preceded by resection of brain metastases.

Material and methods: From 2007 to 2012, 645 patients underwent pulmonary resection for NSCLC at our department. In 25 of them (3.87\%) thoracic surgery was preceded by resection of a single brain metastasis of NSCLC and a PET CT scan. No signs of nodal involvement or distant metastases were detected.

Results: The group consisted of 18 men (72\%) and 7 women (28\%). Average age was 57.62 years (46-70). In all cases, whole brain radiotherapy ( $5 \times 4$ Gy) was performed. The average interval between excision of brain metastasis and lung resection was 31.4 days (27-41). Pneumonectomy was performed in 1 , lobectomy/bilobectomy in 17 and wedge resection in 7 cases. Pathological stage N0 was diagnosed in 17, N1 in 5 and N2 in 3 patients. Average survival was 18.68 months (4-74). Survival at 1,2 and 5 years was $64 \%, 28 \%$ and $28 \%$ respectively. Average disease-free survival was 17.52 months. Histological type $(p=0.57)$ and $\mathrm{G}(p=0.82)$ have no influence on survival. All the patients with hilar lymph node involvement died within 26 months and with mediastinal one within 12 months.

Conclusions: Surgical treatment of patients with NSCLC with synchronous brain metastases may prove beneficial in selected patients after excluding other distant metastases and lymph node involvement.
\end{abstract}

Key words: lung cancer, brain metastases.

\section{Streszczenie}

Wstęp: Leczenie operacyjne niedrobnokomórkowego raka płuca (NDRP) i towarzyszących synchronicznych przerzutów do mózgu jest skuteczniejsze niż inne opcje terapeutyczne, ale postępowanie to nadal pozostaje kontrowersyjne.

Cel pracy: Ocena przeżyć odległych u chorych operowanych radykalnie z powodu raka płuca, u których wcześniej usunięto przerzut raka płuca z mózgowia.

Materiat i metody: W latach 2007-2012 operowano radykalnie 645 chorych z powodu NDRP. Spośród nich u 25 (3,87\%) przed leczeniem torakochirurgicznym usunięto radykalnie przerzut tego raka z mózgowia oraz wykonano pozytonową emisyjną tomografię połączoną z komputerową tomografią rentgenowską (positron emission tomography - computed tomography - PET-CT), nie stwierdzając zajęcia węzłów chłonnych i przerzutów odległych.

Wyniki: W badanej grupie było 18 mężczyzn (72\%), średnia wieku wynosiła 57,62 roku (46-70 lat). U każdego chorego zastosowano uzupełniającą radioterapię głowy (5 × 4 Gy). Czas pomiędzy operacjami wahał się od 27 do 41 dni (średnio 31,4 dnia). Pneumonektomię wykonano u 1 chorego, lobektomię/bilobektomię u 17, a resekcję klinową u 7 chorych. Po operacji stwierdzono brak przerzutów do węzłów u 17, cechę N1 u 5 oraz N2 u 3 chorych. Średni czas przeżycia wynosił 18,68 (4-74) miesiąca. Przeżycie po 1, 2 i 5 latach wynosiło odpowiednio 64,0\%, $28,0 \%$ i $28,0 \%$. Średni czas wolny od nawrotu wynosił 17,52 miesiąca. Typ histologiczny $(p=0,57)$ i stopień zróżnicowania nowotworu $(p=0,82)$ nie wpłynęły na czas przeżycia, wszyscy chorzy z cechą N1 zmarli w ciągu 26 miesięcy, a z cechą N2 w ciągu 12 miesięcy.

Wnioski: Radykalne leczenie operacyjne raka płuca u chorych po uprzednim usunięciu przerzutu z mózgu jest skuteczne u wybranych chorych po wykluczeniu przerzutów odległych w PET-CT i zajęcia węzłów chłonnych metodami inwazyjnymi. Słowa kluczowe: rak płuca, przerzuty do mózgu. 


\section{Introduction}

Lung cancer is the leading cause of cancer death in both men and women in Poland [1]. Brain metastasis is diagnosed clinically in up to $30 \%$ of patients with non-small cell lung cancer (NSCLC) during the course of the disease [2, 3], and in autopsy series the incidence is up to approximately $60 \%$ [4]. Surgical resection of these metastatic lesions is considered in only $25 \%$ of patients [5]. Long-term survival after surgical treatment of metachronous brain metastases in patients with primary NSCLC has been reported in several studies and is promising [6, 7]. However, the results of surgical treatment of synchronous brain metastases along with the primary tumours is controversial $[8,9]$. In this retrospective analysis we present our results of resection of synchronous brain metastases and of the primary NSCLC. In addition, we present prognostic factors affecting survival.

\section{Material and methods}

From January 2007 to December 2012, 645 patients underwent pulmonary resection for non-small cell lung cancer at our department. In 25 of them (3.87\%) surgical treatment for single brain metastases from lung cancer was performed before thoracic surgery. Preoperative workup included positron emission tomography (PET) scan and magnetic resonance imaging or computed tomography (CT) scan of the brain. No signs of residual tumour of the brain, nodal involvement or distant metastases were detected. The medical records of these patients were reviewed. This record was examined for age, sex, histological type and grade, postoperative tumour and nodal stage, surgical procedure, adjuvant therapy and survival. Cerebral and pulmonary resection was considered radical if all macroscopic evidence of disease was removed. Postoperative staging was done according to the International Staging System for Non-Small Cell Lung Cancer (2008). Survival was estimated by the Kaplan-Meier method with the date of pulmonary resection used as the starting point and the date of death or last follow-up as the end point. The influence of variables on survival was analysed by the log-rank test for multivariate analyses.

\section{Results}

The group consisted of 18 men (72\%) and 7 women (28\%). Average age was 57.62 years (range 46-70). The average interval between excision of brain metastases and lung resection was 31.4 days (range from 27 to 41 days). Pneumonectomy was performed in 1 patient, lobectomy/ bilobectomy in 17 and wedge resection in 7 patients (due to compromised cardio-pulmonary function). No patient had preoperative endobronchial ultrasound (EBUS) or mediastinoscopy. Adenocarcinoma was found in 13 cases, squamous-cell carcinoma in 8, large-cell carcinoma in 2 and others in 2 patients. Pathological stage NO was diagnosed in 17 patients, N1 in 5 and N2 in 3 patients.

Whole brain radiotherapy (WBR) $(5 \times 4$ Gy) was applied in every patient after the neurosurgical procedure, before lung resection. Postoperative adjuvant chemotherapy was given in 12 patients (48\%). Patients were selected to receive adjuvant therapy at the discretion of the surgeon and consulting oncologist. Inclusion criteria for chemotherapy were mediastinal or hilar nodal involvement, grade G3 carcinoma (2 cases) and large-cell carcinoma (2 cases)

There were neither perioperative deaths nor serious perioperative complications after pulmonary resection. Follow-up was complete in all patients for a median of 19 months (range 4-74). Recurrence developed in 15 patients (60\%). It was only local in 7 cases $(47 \%)-4$ in the lung and 3 in the brain - and distant in 3 cases (12\%): bone, adrenal, liver. In 5 cases (20\%) both local and distant recurrence developed. No patient underwent late reoperation for recurrent brain metastases. Average survival time was 18.7 months (range from 4 to 74 months). Survival at 1, 2 and 5 years was $64 \%, 28 \%$ and $28 \%$ respectively. Average disease-free survival was 17.5 months. Currently, 10 patients are alive without evidence of recurrent disease (7 of them 60 months or more after pulmonary resection).

Cell type $(p=0.57)$ and $\mathrm{G}(p=0.82)$ have no influence on survival. All the patients who had hilar metastases died within 26 months and those with mediastinal lymph node involvement within 12 months. No statistical significance was calculated because of the small number of cases. Multivariate analysis found that neither age (0.59), sex (0.61), tumour histological type $(p=0.57)$, grade $(p=0.82)$, type of pulmonary resection $(p=0.64)$, nor adjuvant chemotherapy $(p=0.71)$ affected long-term survival.

\section{Discussion}

Cisplatin-based chemotherapy is the gold standard of treatment of disseminated NSCLC [10]. However, solitary metastases to the brain, other lung and adrenal gland, especially metachronous, detected a long time after primary pulmonary resection, are believed resectable, with an acceptable cure rate [11]. The prognosis worsens when the time between treatment of primary tumour and diagnosis of metastasis is shorter, and is believed to be significantly worse for synchronous metastases [12], although some authors observed a better prognosis with synchronous metastases than metachronous brain metastases [9]. When the first symptoms of lung cancer are those caused by distant metastases, usually the only treatment is palliative chemotherapy. However, in recent years a growing role of local treatment (radiation or surgery) of solitary distant metastases has been stressed. An example is solitary metastases to the brain, which can be radically removed by the surgeon, treated with stereotactic radiosurgery (SRS) or gamma-knife radiosurgery (GKRS), often with adjuvant whole brain radiotherapy (WBRT) or systemic cytostatic chemotherapy, followed by radical resection of the primary pulmonary tumour, if no other local or distant metastases are present. This is quite a rare situation, in our series found only in $3.87 \%$ of resected patients, but, because lung cancer is the most common neoplasm, this accounts 
for a meaningful group of patients. Most authors agree that SRS or GKRS gives similarly good local control of brain metastases as surgical resection [13-15], while WBRT is believed to provide shorter median survival [16] (15.4 months vs. 11.5 months, $p=0.002$ ) [14]. Some data show a slightly better prognosis after surgical resection of brain metastases than after SRS [17].

It is widely accepted that after radical treatment of solitary brain metastasis, only patients without other distant metastases and without nodal metastases can be considered candidates for radical surgical treatment. Therefore in our study PET-CT screening was always performed before thoracic surgery. Positron emission tomography-computed tomography is also considered mandatory by other authors, to exclude mediastinal nodal metastases [18]. In our series preoperative staging was based on PET screening, and only patients without suspected metastases to lymph nodes were subsequently operated on. Some authors routinely performed mediastinoscopy in such patients, to exclude N2 disease [15]. However, numerous studies have proved that in patients after radical treatment of synchronous brain metastases, surgery allows better local control and longer median survival than thoracic radiation combined with chemotherapy [19, 20], although others have stressed that not the type of local thoracic treatment but response to preoperative chemotherapy was the main prognostic factor [10]. In the preoperative treatment, the MVP regimen (mitomycin, vinblastine, cisplatin) was, however, poorly tolerated in a phase II trial in NSCLC patients with solitary metastases [21], while newer chemotherapeutic agents seemed to be better tolerated [22]. However, many authors did not report any chemotherapy prior to thoracic surgery.

Similarly as in our study, many authors stress that the absence of nodal metastases is the main factor influencing long-term survival. In many series and case reports, data about cure achieved in stage I disease patients (NO) are provided [18, 23, 24], while lower T-stage was the main factor influencing survival in only one paper [25].

\section{Conclusions}

Surgical treatment of patients with NSCLC with synchronous brain metastases may prove beneficial in selected patients after excluding other distant metastases and lymph node involvement. Survival after resection of the primary tumour in patients with lymph node metastases is very poor; therefore EBUS-TBNA (transbronchial needle aspiration) or mediastinoscopy should be performed routinely in this group of patients.

\section{Disclosure}

Authors report no conflict of interest.

\section{References}

1. Didkowska J. Epidemiologia i etiopatogeneza nowotworów płuca. In: Nowotwory płuca i opłucnej. Jassem J, Krzakowski M (eds.). Via Medica, Gdańsk 2009; 1-14.
2. Knights EM Jr. Metastatic tumors of the brain and their relation to primary and secondary pulmonary cancer. Cancer 1954; 7: 259-265.

3. Sørensen JB, Hansen HH, Hansen M, Dombernowsky P. Brain metastases in adenocarcinoma of the lung: frequency, risk groups, and prognosis. J Clin Oncol 1988; 6: 1474-1480.

4. Billing PS, Miller DL, Allen MS, Deschamps C, Trastek VF, Pairolero PC. Surgical treatment of primary lung cancer with synchronous brain metastases. J Thorac Cardiovasc Surg 2001; 122: 548-553.

5. Kaal EC, Niël CG, Vecht CJ. Therapeutic management of brain metastasis. Lancet Neurol 2005; 4: 289-298.

6. Macchiarini P, Buonaguidi R, Hardin M, Mussi A, Angeletti CA. Results and prognostic factors of surgery in the management of non-small cell lung cancer with solitary brain metastasis. Cancer 1991; 68: 300-304.

7. Mussi A, Pistolesi M, Lucchi M, Janni A, Chella A, Parenti G, Rossi G, Angeletti CA. Resection of single brain metastasis in non-small-cell lung cancer: prognostic factors. J Thorac Cardiovasc Surg 1996; 112: 146-153.

8. Martini N. Rationale for surgical treatment of brain metastasis in non-small cell lung cancer. Ann Thorac Surg 1986; 42: 357-358.

9. Getman V, Devyatko E, Dunkler D, Eckersberger F, End A, Klepetko W, Marta G, Mueller MR. Progmosis of patients with non-small cell lung cancer with isolated brain metastases undergoing combined surgical treatment. Eur J Cardiothorac Surg 2004; 25: 1107-1113.

10. Girard N, Cottin V, Tronc F, Etienne-Mastroianni B, Thivolet-Bejui F, Honnorat J, Guyotat J, Souquet PJ, Cordier JF. Chemotherapy is the cornerstone of the combined surgical treatment of lung cancer: with synchronous brain metastases. Lung Cancer 2006; 53: 51-58.

11. Kozower BD, Lamer JM, Detterbeck FC, Jones DR. Special treatment issues in non-small cell lung cancer: Diagnosis and management of lung cancer, $3^{\text {rd }}$ ed: American College of Chest Physicians evidence-based clinical practice guidelines. Chest 2013; 143 (5 Suppl): e369S-99S.

12. Flannery TW, Suntharalingam M, Kwok Y, Koffman BH, Amin PP, Chin LS, Nicol B, Fowler Z, Young AB, Regine WF. Gamma knife stereotactic radiosurgery for synchronous versus metachronous solitary brain metastases from non-small cell lung cancer. Lung Cancer 2003; 42: 327-333.

13. Griffioen GR, Toguri D, Dahele M, Warner A, de Haan PF, Rodrigues GB, Slotman BJ, Yaremko BP, Senan S, Palma DA. Radical treatment of synchronous oligometastatic non- small cell lung carcinoma (NSCLC): patient outcomes and prognostic factors. Lung Cancer 2013; 82: 95-102.

14. Xu Q, Wang Y, Liu H, Meng S, Zhou S, Xu J, Schmid-Bindert G, Zhou C. Treatment outcome for patients with primary NSCLC and synchronous solitary metastasis. Clin Transl Oncol 2013; 15: 802-809.

15. Mordant P, Arame A, De Dominicis F, Pricopi C, Foucault C, Dujon A, Le Pimpec-Barthes F, Riquet $M$. Which metastasis management allows longterm survival of synchronous solitary M1b non-small cell lung cancer? Eur J Cardiothorac Surg 2012; 41: 617-622.

16. Kim KH, Lee J, Lee J, Nam do H, Kong DS, Ahn YC, Park HC, Kwon OJ, Kim H, Chang MH, Yi SY, Ji SH, Park YH, Ahn IS, Park K, Ahn MI. Can up front systemic chemotherapy replace stereotactic radiosurgery or whole brain radiotherapy in the treatment of non-small cell lung cancer patients with asymptomatic brain metastases? Lung Cancer 2010; 68: 258-263.

17. Bai H, Han B. Surgical treatment for non-small cell lung cancer patients with synchronous solitary brain metastasis. Zhongguo Fei Ai Za Zhi 2013; 16: 646-650.

18. Melloni G, Bandiera A, Gregorc V, Carretta A, Ciriaco P, Vigano M, Franzin A, Bolognesi A, Picozzi P, Zannini P. Combined treatment of non-small cell lung cancer with synchronous brain metastases: a single center experience. J Cardiovasc Surg (Torino) 2011; 52: 613-619.

19. Parlak C, Mertsoylu R, GUler OC, Onal C, Topkan E. Definitive chemoradiation therapy following surgical resection or radiosurgery plus whole-brain radiation therapy in non-small cell lung cancer patients with synchronous solitary brain metastasis: a curative approach. Int J Radiat Oneal Biol Phys 2014; 88: 885-891.

20. Lind JS, Lagerwaard FJ, Smit EF, Postmus PE, slotman Bl, Senan S. Time for reappraisal of extracranial treatment options? Synchronous brain metastases from nonsmall cell lung cancer. Cancer 2011; 117: 597-605.

21. Downey RJ, Ng KK, Kris MG, Bains MS, Miller VA, Heelan R, Bilsky M, Ginsberg R, Rusch VW. A phase II trial of chemotherapy and surgery for nonsmall cell lung cancer patients with a synchronous solitary metastasis. Lung Cancer 2002; 38: 193-197.

22. De Ruysscher D, Wanders R, van Baardwijk A, Dingemans AM, Reymen B, Rouben R, Bootsma G, Pitz C, van Eijsden L, Geraedts W, Baumert BG, Lam- 
bin P. Radical treatment of non-small-cell lung cancer patients with synchronous oligometastases: long-term results of a prospective phase II trial (Nct01282450). J Thorac Oncol 2012; 7: 1547-1555.

23. Funai K, Suzuki K, Sekihara K, Shimizu K, Shiiya N. Five-year tumor-free survival after aggressive trimodality therapy for T3NOMlb non-small cell lung cancer with synchronous solitary brain metastasis. Gen Thorac Cardiovasc Surg 2012; 60: 370-372.

24. Gray PJ, Mak RH, Yeap BY, Cryer SK, Pinnell NE, Christianson LW, Sher DJ, Arvold ND, Baldini EH, Chen AB, Kozono DE, Swanson SJ, Jackman DM, Al- exander BM. Aggressive therapy for patients with non-small cell lung carcinoma and synchronous brain- only oligometastatic disease is associated with long-term survival. Lung Cancer 2014; 85: 239-244.

25. Collaud S, Stahel R, Inci I, Hillinger S, Schneiter D, Kestenholz P, Weder W. Survival of patients treated surgically for synchronous single-organ metastatic NSCLC and advanced pathologic TN stage. Lung Cancer 2012; 78: 234-238. 